\title{
Article \\ Bacteria Cell Hydrophobicity and Interfacial Properties Relationships: A New MEOR Approach
}

\author{
Ehsan Ganji-Azad ${ }^{1}$, Aliyar Javadi ${ }^{1,2, * \mathbb{D}}$, Moein Jahanbani Veshareh ${ }^{3}$, Shahab Ayatollahi ${ }^{4} \mathbb{D}$ \\ and Reinhard Miller ${ }^{5}$ iD
}

1 Chemical Engineering Department, College of Engineering, University of Tehran, Tehran 11155-4563, Iran; ganjiazad@ut.ac.ir

2 Institute of Process Engineering and Environmental Technology, Technische Universität Dresden, D-01069 Dresden, Germany

3 Danish Hydrocarbon Research and Technology Center, Denmark Technical University, 2800 Kongens Lyngby, Denmark; moein@dtu.dk

4 School of Chemical \& Petroleum Engineering, Sharif University of Technology, Tehran 11155-1639, Iran; shahab@sharif.edu

5 Physics Department, Technical University Darmstadt, 64289 Darmstadt, Germany; miller@fkp.tu-darmstadt.de

* Correspondence: javadi.aliyar@ut.ac.ir or aliyar.javadi@tu-dresden.de

check for updates

Citation: Ganji-Azad, E.; Javadi, A.; Jahanbani Veshareh, M.; Ayatollahi,

S.; Miller, R. Bacteria Cell

Hydrophobicity and Interfacial

Properties Relationships: A New MEOR Approach. Colloids Interfaces 2021, 5, 49. https://doi.org/10.3390/ colloids5040049

Academic Editors: Victor Starov and Anna Trybala

Received: 28 June 2021

Accepted: 15 November 2021

Published: 19 November 2021

Publisher's Note: MDPI stays neutral with regard to jurisdictional claims in published maps and institutional affiliations.

Copyright: (c) 2021 by the authors. Licensee MDPI, Basel, Switzerland. This article is an open access article distributed under the terms and conditions of the Creative Commons Attribution (CC BY) license (https:// creativecommons.org/licenses/by/ $4.0 /)$

\begin{abstract}
For microbial enhanced oil recovery (MEOR), different mechanisms have been introduced In some of these papers, the phenomena and mechanisms related to biosurfactants produced by certain microorganisms were discussed, while others studied the direct impacts of the properties of microorganisms on the related mechanisms. However, there are only very few papers dealing with the direct impacts of microorganisms on interfacial properties. In the present work, the interfacial properties of three bacteria MJ02 (Bacillus Subtilis type), MJ03 (Pseudomonas Aeruginosa type), and RAG1 (Acinetobacter Calcoaceticus type) with the hydrophobicity factors 2,34 , and $79 \%$ were studied, along with their direct impact on the water/heptane interfacial tension (IFT), dilational interfacial visco-elasticity, and emulsion stability. A relationship between the adsorption dynamics and IFT reduction with the hydrophobicity of the bacteria cells is found. The cells with highest hydrophobicity $(79 \%)$ exhibit a very fast dynamic of adsorption and lead to relatively large interfacial elasticity values at short adsorption time. The maximum elasticity values (at the studied frequencies) are observed for bacteria cells with the intermediate hydrophobicity factor (34\%); however, at longer adsorption times. The emulsification studies show that among the three bacteria, just RAG1 provides a good capability to stabilize crude oil in brine emulsions, which correlates with the observed fast dynamics of adsorption and high elasticity values at short times. The salinity of the aqueous phase is also discussed as an important factor for the emulsion formation and stabilization.
\end{abstract}

Keywords: microbial enhanced oil recovery (MEOR); hydrophobicity of bacteria cells; interfacial properties; dilational visco-elasticity; emulsion stability; salinity effects; diffusion and adsorption

\section{Introduction}

For most of the oil reservoirs, just a small percentage (less than $20 \%$ ) of the original oil in place can be extracted via the natural pressure of the reservoir, combined with gravitational drainage and supported by external forces like pumps. Therefore, extensive studies have been performed to find methods of enhanced oil recovery (EOR), and even a $1 \%$ improvement can be an important achievement for large scale oil reservoirs. However, most of these methods are not yet economically feasible or environmentally friendly [1] for practical applications in the field, and successful projects are often case study dependent. Among these methods, Microbial Enhanced Oil Recovery (MEOR) is one of the promising approaches [2]. In this bio-technological EOR procedure, different microorganisms and bioproducts are utilized in order to increase the oil recovery through in/ex situ processes [3,4]. 
Several field trials have been reported that illustrate the advantages of MEOR to effectively increase oil recovery [4]. However, there are still several open issues for the practical implementation of MEOR, including the complexity of the mechanisms, the instability of the field trails, low ultimate recovery, cost-effective production of microbial products, and lack of appropriate mathematical models for a process optimization.

According to some review studies [4-6], the MEOR mechanisms can be classified mainly as: improving the mobility ratio by oil viscosity reduction, biopolymer production, bioclogging and permeability modifications, biodegradation, IFT reduction, emulsification, and wettability alteration, via the metabolism of related bioproducts [7-13]. However, for hydrophobic microorganism, other mechanisms can play certain roles and can also influence the oil recovery directly (in addition to the role of bioproducts). Sarafzadeh et al. [14] showed that the adhesion of the cells of the special hydrophobic strain, Bacillus stearothermophilus SUCPM\#14, at the oil/water interface leads to an increased oil recovery as a result of the changed oil/water interfacial behavior. However, interfacial dilational visco-elasticity was not investigated in their work, which is now part of this study. It will be discussed that the attachment of B. stearothermophilus SUCPM\#14 at the oil/water interface can cause high elasticity values, which is an important factor for EOR.

Dorobantu et al. showed that the hydrophobic strain, Acinetobacter venetianus RAG-1, stabilizes both oil in water and water in oil emulsions without affecting the IFT [15]. They illustrated that the mechanism responsible for stabilizing the emulsion is inhibition of droplet coalescence. Via direct contact experiments, Kang et al. indicated that the two strains Acinetobacter venetianus RAG-1 and Rhodococcus erythropolis 20S-E1-c act as effective stabilizers. In this work, it was shown that the mechanism of emulsion stabilization consists of: (a) the creation of steric barriers due to the presence of microorganism cells at the interface, and (b) the increase of the interfacial activity due to the interaction of adsorbed cells at the interface [16]. In another work, Kang et al. showed that the presence of two different strains, $A$. venetianus RAG-1 and R. erythropolis 20S-E1-c, has negligible effects on the oil/water IFT, changing IFT values only from $52 \mathrm{mN} / \mathrm{m}$ to $49 \pm 1.5 \mathrm{mN} / \mathrm{m}$ and $48.5 \pm 1.2 \mathrm{mN} / \mathrm{m}$, respectively [17].

In contrast to Dorobantu et al. (2004) and Kang et al. (2008) who refuted any significant surface activity for microorganism cells, Karimi et al. showed that the presence of cells of the hydrophilic strain Enterobacter cloacae can decrease the surface tension (ST) of water noticeably from $68.2 \pm 0.9 \mathrm{mN} / \mathrm{m}$ to $56.5 \pm 1.1 \mathrm{mN} / \mathrm{m}$ [13]. This indicates a significant surface activity for these microorganism cells. Halim et al. showed that bacteria themselves can play an important role in the formation of emulsions, even in cases where a limited IFT reduction takes place. Their results demonstrate that the emulsion formation in combination with a reduced IFT is an important mechanism for MEOR applications [18].

In summary, although MEOR processes are generally discussed based on the impacts of the related biosurfactant products, the direct impacts of the microorganism on interfacial properties can be also an important issue. On the other hand, the production of biosurfactants may have several restrictions such as requirements of specific minerals and $\mathrm{pH}$ conditions in the reservoir [19]. Furthermore, isolation and purification of the individual components can be expensive [20], and any utilization of biosurfactants in ex-situ processes might be economically infeasible. Furthermore, for in-situ processes, the utilization of biosurfactants is limited to the presence of an indigenous biosurfactants producing strain. Similar restrictions exist for the MEOR method through employing other mechanisms, such as the need of special nutritional components and the presence of special strains. Thus, finding new MEOR methods which are less dependent on the production of biosurfactants can be captivating.

Therefore, the adsorption of the microorganism cells at the water-oil interface can activate an enhanced oil recovery directly. IFT reduction and emulsion formation are two proposed mechanisms for MEOR [21,22]. However, the fundamental phenomena behind these mechanisms must be investigated and further clarified. Thus, the relationships between the hydrophobicity of the bacteria cells and the dynamic IFT and interfacial vico- 
elasticity values of the related solutions, as key factors in the discussed mechanism, are investigated in this work.

\section{Materials and Methods}

Experiments are divided into two categories: bacterial cell isolation and identification, and impact of their hydrophobicity on interfacial properties.

\subsection{Microorganisms}

Three bacteria were investigated in this work, one of them is the known microorganism RAG1; the second was isolated from an oil production unit, and the third one from seawater (Table 1). These three bacteria cover a wide range of hydrophobicity $(2,34$, and $79 \%)$, and of the resources that can be used for EOR applications (injection of brine or sea water).

Table 1. Specifications of used bacteria.

\begin{tabular}{ccccc}
\hline $\begin{array}{c}\text { Sample of } \\
\text { Bacteria }\end{array}$ & $\begin{array}{c}\text { Source/Name of } \\
\text { Bacteria }\end{array}$ & Hydrophobicity & Bacteria Cell & Size \\
\hline Sample A & $\begin{array}{c}\text { Isolated from sea } \\
\text { water }(M J 02)\end{array}$ & $2 \%$ & Bacillus subtilis & $\begin{array}{c}0.25-1 \mu \mathrm{m} \text { Diameter } \\
4-10 \mu \mathrm{m} \text { Length }\end{array}$ \\
& $\begin{array}{c}\text { Isolated from } \\
\text { Iranian oil field } \\
(M J 03)\end{array}$ & $34 \%$ & $\begin{array}{c}\text { Pseudomonas } \\
\text { aeruginosa }\end{array}$ & $\begin{array}{c}0.5-0.8 \mu \mathrm{m} \text { Diameter } \\
1.5-3 \mu \mathrm{m} \text { Length }\end{array}$ \\
Sample B & $R A G 1$ & $79 \%$ & $\begin{array}{c}\text { Acinetobacter } \\
\text { calcoaceticus }\end{array}$ & $\begin{array}{c}1-1.5 \mu \mathrm{m} \text { Diameter } \\
1.5-2.5 \mu \mathrm{m} \text { Length }\end{array}$ \\
\hline
\end{tabular}

\subsubsection{Isolation}

The isolation processes for two of the mentioned bacteria are described as follows.

Isolation of Oil Degrading Bacteria

The samples from the soil of oil contaminated areas, and brine from the bottom of the stock tank were collected in sterile containers from an oil production unit in the south of Iran. A total of $2 \mathrm{~g}$ of the soil samples and $2 \mathrm{~mL}$ of the brine samples were added to $50 \mathrm{~mL}$ of a mineral salt based enrichment medium in $250 \mathrm{~mL}$ conical flasks. The following medium, which has been proposed by Peng et al. [23], was used as an enrichment medium (adjusted to pH 7.4): $\left(\mathrm{NH}_{4}\right)_{2} \mathrm{SO}_{4}, 10 \mathrm{~g} / \mathrm{L}, \mathrm{NaCl}, 15 \mathrm{~g} / \mathrm{L} ; \mathrm{FeSO}_{4} \cdot 7 \mathrm{H}_{2} \mathrm{O}, 2.8 \times 10^{-4} \mathrm{~g} / \mathrm{L}$; $\mathrm{KH}_{2} \mathrm{PO}_{4}, 3.4 \mathrm{~g} / \mathrm{L} ; \mathrm{K}_{2} \mathrm{HPO}_{4} \cdot 3 \mathrm{H}_{2} \mathrm{O}, 4.4 \mathrm{~g} / \mathrm{L} ; \mathrm{MgSO}_{4} \cdot 7 \mathrm{H}_{2} \mathrm{O}, 1.02 \mathrm{~g} / \mathrm{L} ;$ yeast extract, $0.5 \mathrm{~g} / \mathrm{L}$, and trace element solution, $0.5 \mathrm{~mL} / \mathrm{L}$ with $2 \%(v / v)$ n-hexadecane as the sole carbon source. The following trace element solution after separate sterilization should be added to the preceding medium: $\mathrm{ZnSO}_{4}, 0.29 \mathrm{~g} / \mathrm{L} ; \mathrm{CaCl}_{2}, 0.24 \mathrm{~g} / \mathrm{L} ; \mathrm{CuSO}_{4}, 0.25 \mathrm{~g} / \mathrm{L} ; \mathrm{MnSO}_{4}, 0.17 \mathrm{~g} / \mathrm{L}$. The enrichment process was conducted at $30^{\circ} \mathrm{C}, 160$ rpm over 5 days.

After the enrichment process, various dilutions of the cultures up to $10^{8}$ were prepared and spread on Luria-Bertani agar medium, which is composed of tryptone, $10 \mathrm{~g} / \mathrm{L}$; yeast extract, $5 \mathrm{~g} / \mathrm{L} ; \mathrm{NaCl}, 5 \mathrm{~g} / \mathrm{L}$; agar, $15 \mathrm{~g} / \mathrm{L}$. After $1-3$ days incubation at $30^{\circ} \mathrm{C}$, morphologically different colonies were re-cultivated on fresh agar plates at least for three times to obtain pure cultures. Afterward, the purity of these isolates was confirmed through Gram staining [24].

In order to ensure that all potential strains have been successfully isolated, a second enrichment method proposed by Bushnell Haas was applied. The enrichment medium of this method was composed of: $\mathrm{MgSO}_{4}, 0.2 \mathrm{~g} / \mathrm{L} ; \mathrm{CaCl}_{2}, 0.02 \mathrm{~g} / \mathrm{L} ; \mathrm{KH}_{2} \mathrm{PO}_{4}, 1 \mathrm{~g} / \mathrm{L} ; \mathrm{K}_{2} \mathrm{HPO}_{4}$, $1 \mathrm{~g} / \mathrm{L} ;\left(\mathrm{NH}_{4}\right)_{2} \mathrm{SO}_{4}, 1 \mathrm{~g} / \mathrm{L} ; \mathrm{FeCl}_{3}, 0.05 \mathrm{~g} / \mathrm{L}$; with $1 \%(v / v)$ n-hexadecane as the sole carbon source. The medium was adjusted to $\mathrm{pH}$ 7-7.2. After preparation of the medium, the enrichment was conducted at $30^{\circ} \mathrm{C}$ over 1 month (no shaking) [25]. 


\section{Isolation of Sea Water Bacteria}

For isolation of each bacteria cell, we need different enrichment medium, which depends on its source. However, these media were used for isolation, purification, and screening of the bacteria cells and after choosing the proper microorganisms, all of them were grown in the same LB medium (in Luria Bertani agar medium). Samples of seawater from the Persian Gulf were taken from a location far from the beach and it was roughly $1 \mathrm{~m}$ below the see floor in order to ensure the water sample was free of near beach pollution effects. The following medium (seawater broth) was used for isolating the sea water microorganisms: Peptone, $5 \mathrm{~g} / \mathrm{L}$; yeast extract, $5 \mathrm{~g} / \mathrm{L}$; beef extract, $3 \mathrm{~g} / \mathrm{L}$; sea water $1 \mathrm{~L}$ [26]. After preparation, $500 \mu \mathrm{L}$ of the seawater sample was inoculated to $50 \mathrm{~mL}$ of this medium in a $250 \mathrm{~mL}$ conical flask.

Like in the previous section, after the enrichment process different dilutions of the cultures up to $10^{8}$ were prepared and spread on a sea water agar medium, which has the same composition as seawater broth plus $15 \mathrm{~g} / \mathrm{L}$ of agar. Other steps were done as in the previous section, except the Bushnell Haas method was not used.

\subsubsection{Identification}

Chromosomal DNA of screened bacteria was extracted using a CinnaPure TM DNA extraction kit (Cinnagen, Iran) according to the manufacturer's instructions. The 16S rRNA gene was amplified by PCR using a universal primer: F: AGAGTTTGATCCTGGCTCAG, R:ACGGCTACCTTGTTACGACTT [27] The reaction was performed in a total volume of $20 \mu \mathrm{L}$ and was set up as follows: $7 \mu \mathrm{L}$ of PCR master mix (Amplicon, Denmark), $1 \mu \mathrm{L}$ of each F and R primer, 1 ng of template DNA, and remaining volume $(10 \mu \mathrm{L})$ of sterile distilled water. The thermal condition was carried out in these steps: $94{ }^{\circ} \mathrm{C}$ for $5 \mathrm{~min}$ as initial denaturation, and 35 cycles at $94{ }^{\circ} \mathrm{C}$ for $30 \mathrm{~s}, 57^{\circ} \mathrm{C}$ of annealing for 30 and $105 \mathrm{~s}$ for extension at $72{ }^{\circ} \mathrm{C}$, the PCR was terminated with $10 \mathrm{~min}$ at $72{ }^{\circ} \mathrm{C}$. The amplified product was detected on $1 \%$ gel electrophoresis, and the band similar to $1513 \mathrm{bp}$ was cut and extracted by a gel elution kit (GenMark Technology, Taichung, Taiwan). The extracted band then was sequenced by the Macrogen Service Centre Advancing (Korea). The resulting sequence homology was compared to the GenBank database of the National Centre for Biotechnology Information (NCBI) using the BLASTn algorithm. The CLustalW was used for nucleotide sequence alignment. The neighbor joining tree construction was carried out using the Molecular Evolutionary Genetics Analysis (MEGA) software version 6.0 [28]. A detailed description of the identification procedure utilized in this work can be found in [29].

\subsubsection{Previously Known Microorganisms}

The Acinetobacter calcoaceticus PTCC 1318 strain (RAG1) was purchased from Persian type culture collection (Iran) [29,30].

\subsubsection{Microorganism Growth Conditions}

The cultures were grown at $35^{\circ} \mathrm{C}$ in Luria Bertani medium (LB), which is composed of tryptone, $10 \mathrm{~g} / \mathrm{L}$; yeast extract, $5 \mathrm{~g} / \mathrm{L} ; \mathrm{NaCl}, 5 \mathrm{~g} / \mathrm{L}$; on a rotary shaker at $160 \mathrm{rpm}$; the cells, at the start of their stationary phase, were subsequently harvested by centrifugation at $8000 \times g$. Cells were washed three times and re-suspended in potassium phosphate buffer at $\mathrm{pH} 7$ at the specified molarity.

\subsubsection{Adhesion Experiments}

In order to determine the affinity of the cells of different strains to adhere to the oil/water interface, a bacterial adhesion to hydrocarbons (BATH, used as hydrophobicity index) test was used as proposed by Rosenberg et al. [31].

The cells, already harvested and washed, were then suspended in phosphate buffer so that the mixture's initial optical density at $600 \mathrm{~nm}$ (OD600) was obtained. Afterward, an aliquot of the cell suspension (1.2 mL) was mixed with $1 \mathrm{~mL}$ of $\mathrm{n}$-hexadecane $(99 \%$ pure; 
Sigma Chemical Co., St. Louis, Mo.) for $120 \mathrm{~s}$ using a vortex mixer. After phase separation (15 min) the optical density of the aqueous phase was measured again. To determine the adhesion in percent, we utilized the relative difference between the aqueous phase's optical density before and after mixing with $n-C_{16}$.

$$
\text { BATH }=100 \times\left[1-\left(\frac{\text { OD600 after mixing }}{\text { OD600 before mixing }}\right)\right]
$$

\subsection{Measurements of the Interfacial Properties}

For measuring dynamic interfacial tension, the drop profile analysis tensiometer PAT-1 (SINTERFACE Technologies, Berlin) was used; a detailed description of this apparatus can be found in $[32,33]$. In brief, the instrument has a dosing system with the accuracy of $\pm 0.02 \mu \mathrm{L}$ connected to the tip of a capillary. The drop is created at the capillary tip manually, which can be afterwards adjusted automatically to a certain constant volume (or area) via the syringe pump with subsequent programmable arbitrary volume/area changes (e.g., oscillation, ramp expansion/contraction, etc.). Then, the drop profiles recorded via a CCD camera are used for IFT measurements by fitting the Young-Laplace equation to the drop profile coordinates.

In order to achieve a bacteria cell adsorption equilibrium at the interface, dynamic interfacial tensions are measured within a range of $1500 \mathrm{~s}$. Additionally, the interfacial dilational visco-elasticity is measured at two time moments. The frequency range of these measurements were between 0.01 to $0.1(\mathrm{~Hz})$ and the amplitude was about $7 \%$ of the drop volume.

The dilatational visco-elasticity modulus $(E)$ is defined as follows [34]

$$
E=\frac{\mathrm{d} \gamma}{\mathrm{d} \ln \mathrm{A}}
$$

The drop oscillations were generated at two different drop ages of about 100-400 and 900-1200 s for better recognition of the adsorbed layer composition at early stages and later times of adsorption layer formation.

\subsection{Emulsion Stabilization Study}

The crude oil used in this study was obtained from one of the Iranian south oil fields and consists of $57 \%$ saturates, $21 \%$ aromatics, $21 \%$ resin, and $2 \%$ asphaltene. The other properties of this crude oil are presented in Table 2.

Table 2. Properties of the crude oil.

\begin{tabular}{lcc}
\hline \multicolumn{1}{c}{ Property } & Unit & Value \\
\hline Specific Gravity & $\mathrm{API}$ & 30.58 \\
Dead oil Viscosity & $\mathrm{Cp}$ & 4.8 \\
Saturations Content & $\mathrm{Wt} \%$ & 57 \\
Aromatics Content & $\mathrm{Wt} \%$ & 21 \\
Resins Content & $\mathrm{Wt} \%$ & 21 \\
Asphaltenes Content & $\mathrm{Wt} \%$ & 2 \\
\hline
\end{tabular}

Firstly, for preparing cell suspensions, the cells were three times washed in a concentration of $1500 \mathrm{ppm}$ in distilled water of different salinities of $\mathrm{NaCl}$. Afterward, $3 \mathrm{~mL}$ of these solutions were added to $3 \mathrm{~mL}$ of a dead oil in $10 \mathrm{~mL}$ test tubes. Subsequently, oil and water in each test tube were mixed for $5 \mathrm{~min}$ using a high speed vortex mixer. Thereafter, the volumes of the emulsion (Ve), water (Vw) and oil (Vo) phases were measured after $15 \mathrm{~min}$ and $24 \mathrm{~h}$. Furthermore, in order to demonstrate the effects of salinity on the emulsion formations, the volume ratios $\mathrm{Vo} / \mathrm{Ve}$ and $\mathrm{Vw} / \mathrm{Ve}$ were plotted against salinity. For the determination of the emulsion stability, the initial emulsion volume was compared with 
that after $24 \mathrm{~h}$, and the volume ratios $\mathrm{Ve}{ }_{(\text {after } 24 \mathrm{~h}) / \mathrm{Ve}}$ (initial) were plotted against salinity as emulsion stability index.

\section{Results and Discussion}

The results of the BATH tests illustrate a wide hydrophobicity range between 2 and $79 \%$ for the selected bacteria (Table 1), which is suitable for investigating the effect of hydrophobicity of bacteria cells on the interfacial properties.

\subsection{Identification of the Bacteria}

The 16S rRNA partial sequence analysis showed that MJ02 and MJ03 are Bacillus subtilis and Pseudomonas aeruginosa by 97 and 96\% similarity, respectively. The 16S rRNA of these strains was submitted to NCBI GenBank with the accession numbers MH244902 and MH290000, respectively.

\subsection{Dynamic Interfacial Tension of Aqueous Suspensions of the Pure Bacteria Cells}

The first set of experiments was conducted with bacteria cell suspensions in absence of any bio product. This reflects the distinct effects of the bacteria cells on the interfacial properties. Figure 1 shows the dynamic IFT of the n-heptane/water system in presence of the bacteria samples A, B, and C at three different concentrations each. We can observe that the microorganisms attach at the interface, which leads to a remarkable decrease in IFT; these effects increase with the hydrophobicity and concentration of the cells, as expected. To clarify the effects of the hydrophobicity, the results for different bacteria at the concentration of 500 ppm are presented in Figure 2 in which the most significant effect on IFT is observed for the bacteria sample $C$ with the highest hydrophobicity $79 \%$. Therefore, it can be concluded that the ability of the microorganism cells to reduce the oil/water IFT is correlated reasonably with their hydrophobicity.

\subsection{Analysis of the Adsorption Kinetics}

Diffusion-controlled, kinetic-controlled, and mixed diffusion-kinetics-controlled models are known for the description of the adsorption kinetics of surfactants at liquid interfaces. In the diffusion-controlled model, it is assumed that the required time for a component to be transported from the bulk to the sublayer is much greater than the transfer time of a cell from the sublayer to the adsorbed state at the interface [35], which may need additional time for hydrophobic-hydrophilic heads, tails, and chains to re-orient and re-configure at the interface. The following equation describes the diffusion-controlled model for short adsorption times best [36]:

$$
\gamma(\mathrm{t})=\gamma(0)-2 \operatorname{RTC}\left(\frac{\mathrm{Dt}}{\pi}\right)^{1 / 2}
$$

Here, $\gamma$ is dynamic interfacial tension, $\gamma(0)$ is the initial interfacial tension at $t=0, R$ is the universal gas constant, $\mathrm{T}$ is the absolute temperature, $\mathrm{C}$ is the bulk concentration of the adsorbing molecules, and $\mathrm{D}$ is the diffusion coefficient.

Figure 3 shows the dynamic IFT versus square root of time of the adsorption process. Regarding Equation (3), the linear relationship between IFT and square root of time shows that the bacteria cells adsorb diffusion-controlled for all three samples. Due to the higher surface activity for the sample $C$, the dynamics of adsorption appears faster than others at the same concentration. The interesting point for all of these three bacteria is a high motility and super-diffusivity (estimated D: order of $10^{-9} \mathrm{~m}^{2} / \mathrm{s}$ ) of such a large surface active component (size scale $0.25-1 \mu \mathrm{m}$ diameter, and 1-10 $\mu \mathrm{m}$ long) in comparison with regular surfactant molecules, which are much smaller (e.g., typically range of 1-2 nm), and large protein macromolecules (e.g., range of 10-20 nm). This is however a known phenomenon in the hydrodynamics of microorganisms that show a motility supported by a self-propelled enhanced Brownian motion mechanism [37]. This can also be estimated via our experimental data given in Figure 3. The faster adsorption of RAG1 can also be due 
to a higher motility of these bacteria according to its higher hydrophobicity, which may lead to a stronger self-propulsion property.

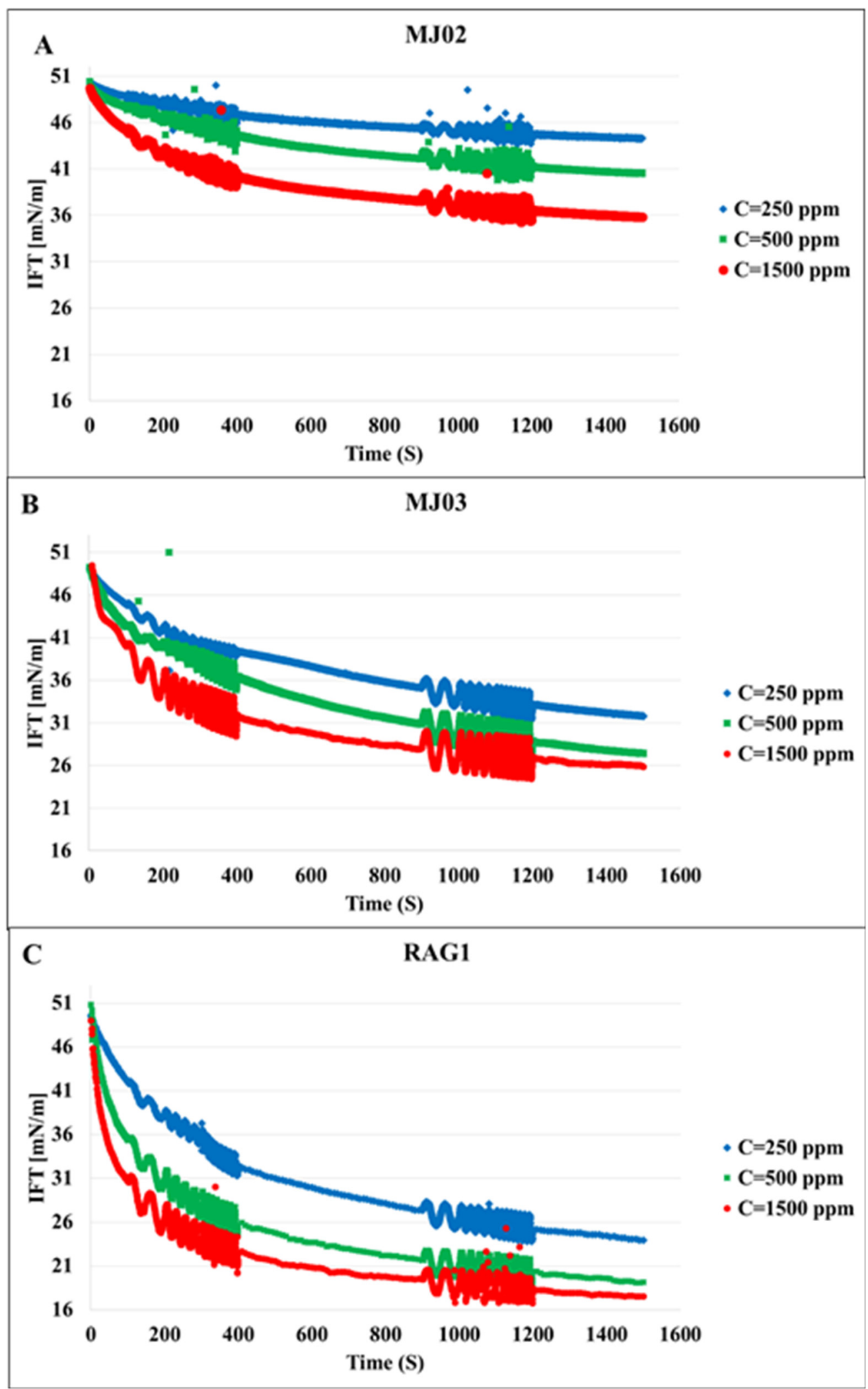

Figure 1. Dynamic interfacial tension for three different bacteria samples at different cell concentrations (given in the insert in ppm). (A), MJ02; (B), MJ03; (C), RAG1. 


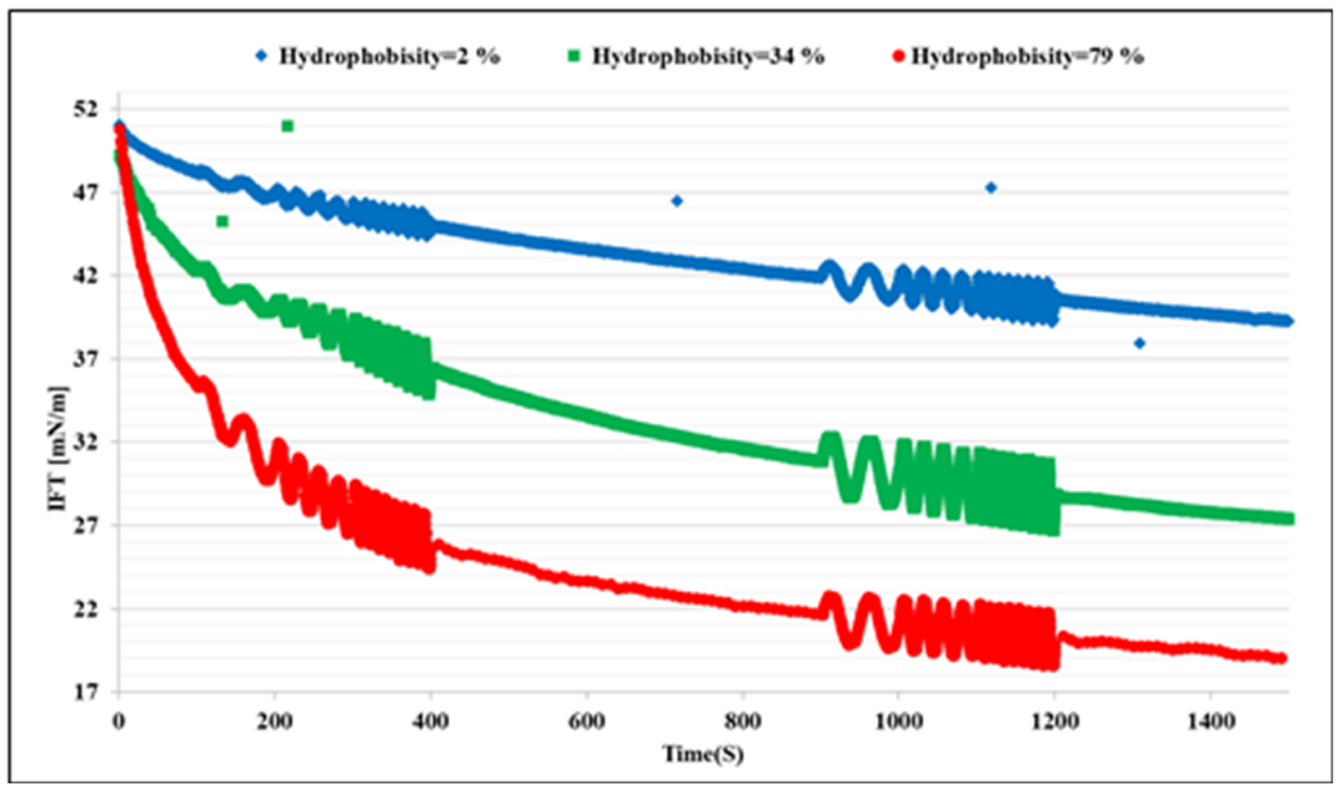

Figure 2. Impacts of the bacteria hydrophobicity on the dynamic interfacial tension evolutions at a fixed bacteria concentration of $500 \mathrm{ppm}$.

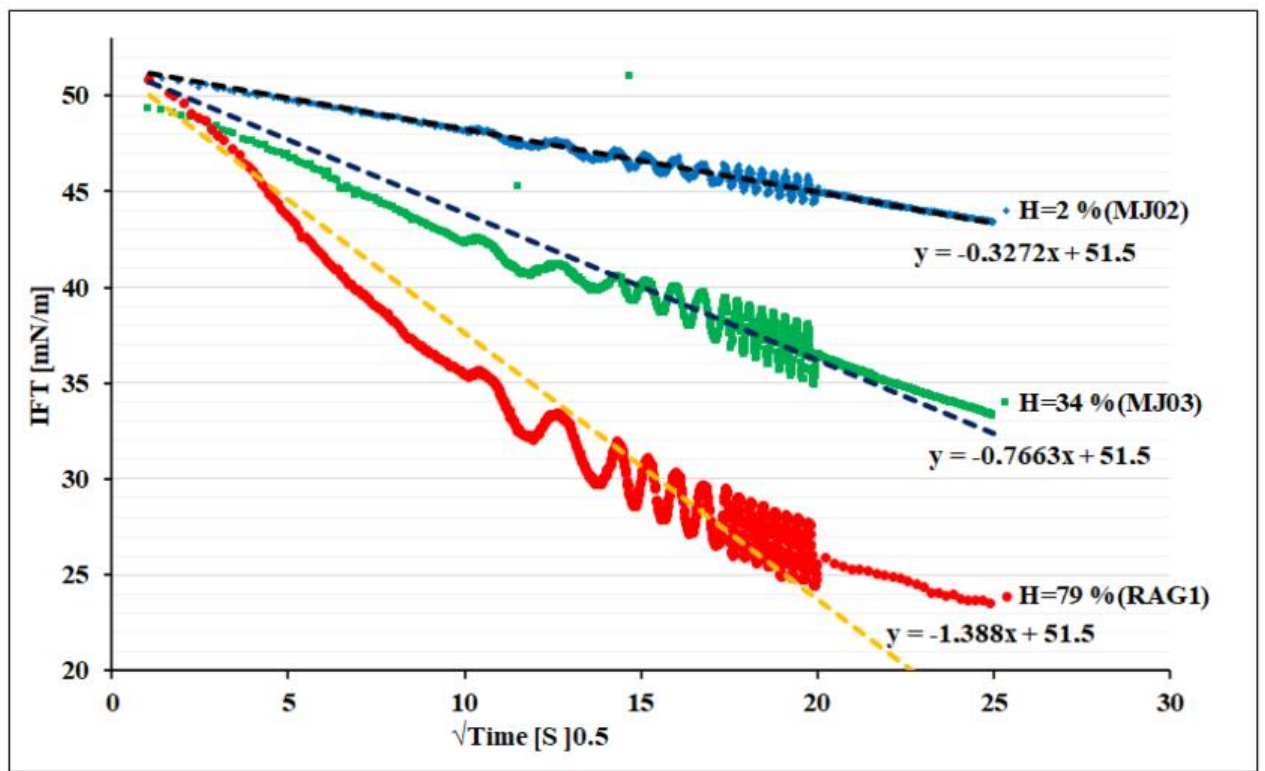

Figure 3. Dynamic IFT versus square root of time for bacteria of different hydrophobicity (H).

Note, the hydrophobicity factor can also play a role in the final step of the adsorption at interface, as it can influence the orientation and configuration states close to the interface. Thus, the consequent mechanism of the adsorption process can become mixed-kineticsdiffusion controlled, which would need a careful discussion with extra experimental data obtained with complementary protocols and techniques.

\subsection{Measurements of the Interfacial Dilational Visco-Elasticity}

Figure 4 shows the elasticity values of the aqueous bacteria suspensions at different concentrations against heptane measured at two different adsorption times: 100-400 and 900-1200 s after the formation of the drop interface. For longer adsorption times, the elasticity values are higher due to the higher adsorbed amount of bacteria cells at the interface. This difference is less for higher concentrations due to the faster adsorption process. The maximum elasticity is observed for the bacteria MJ03, which is expected 
according to the rate of adsorption presented in Figure 2, which indicates a significant, however gradual, decrease in surface tension.

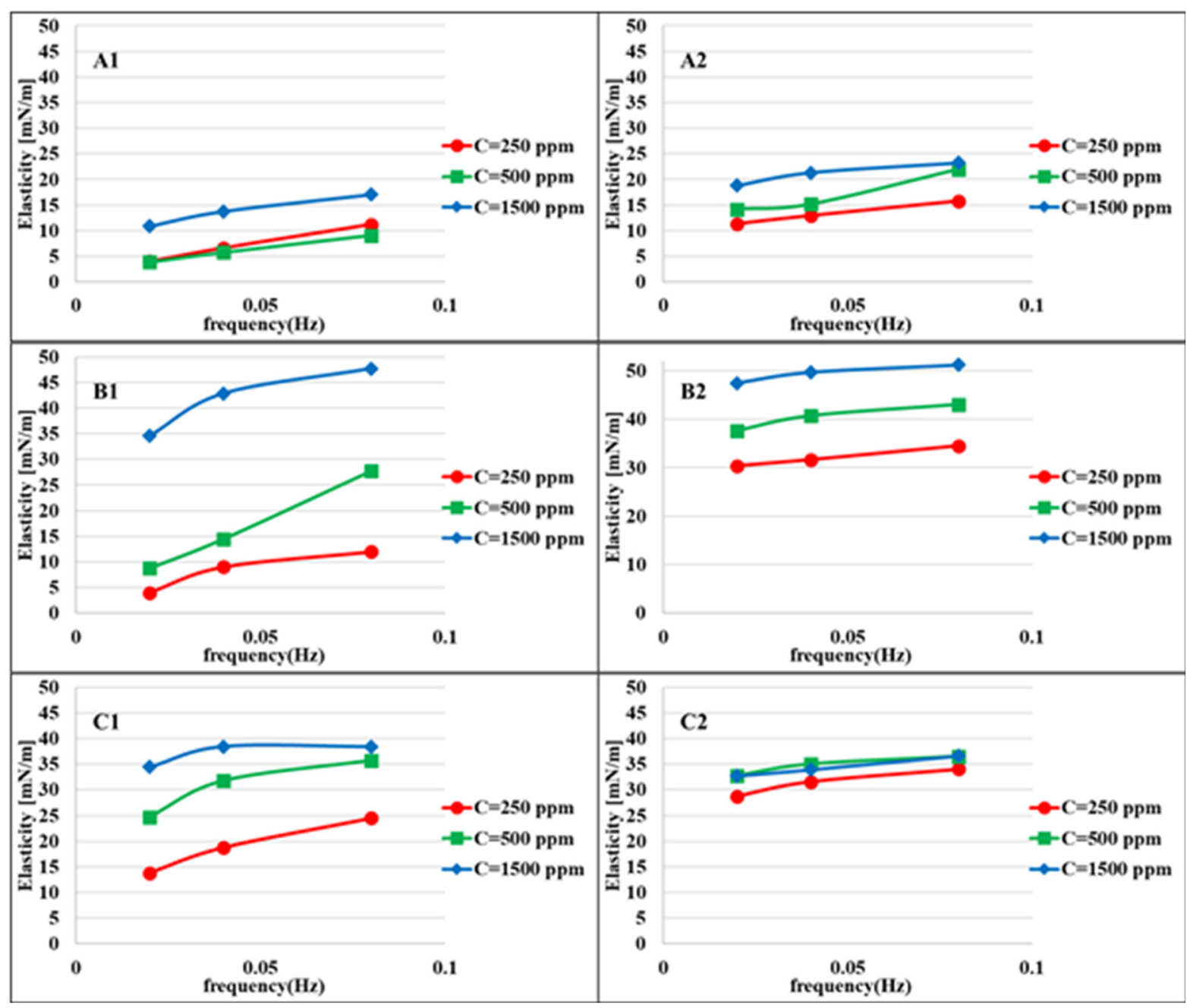

Figure 4. Interfacial dilational elasticity for suspensions of bacteria with different hydrophobicity measured at different adsorption layer ages and different frequencies at the water/heptane interface: (A1) (MJ02, $\mathrm{H}=2 \%$, first period $\mathrm{t}=100-400 \mathrm{~s})$; (A2) (second period $\mathrm{t}=$ 900-1200 s); (B1) $(\mathrm{MJ03}, \mathrm{H}=34 \%$, first period); (B2), (second period); (C1), (RAG1, $\mathrm{H}=79 \%$, first period); (C2) (second period).

The elasticity values depend very much on the hydrophobicity, adsorption time, and bacteria concentration. For easier interpretation, the results in Figure 5 are shown as a function of the hydrophobicity $(\mathrm{H})$. The maximum elasticity for the first period of adsorption (100-400), and for the high concentration range (1500 ppm) MJ03 shows a maximum elasticity. For longer adsorption times (second period, 900-1200 s), MJ03 has a maximum elasticity at all concentrations. For RAG1 at high concentrations, we see a decrease in the elasticity at the measured frequencies of 0.02 and $0.08 \mathrm{~Hz}$, which is due to the fast adsorption kinetics (observed via dynamic interfacial tensions). However the results can be different for very high frequencies, for which alternative experimental techniques based, for instance, on capillary pressure measurements would be required [38,39]. 


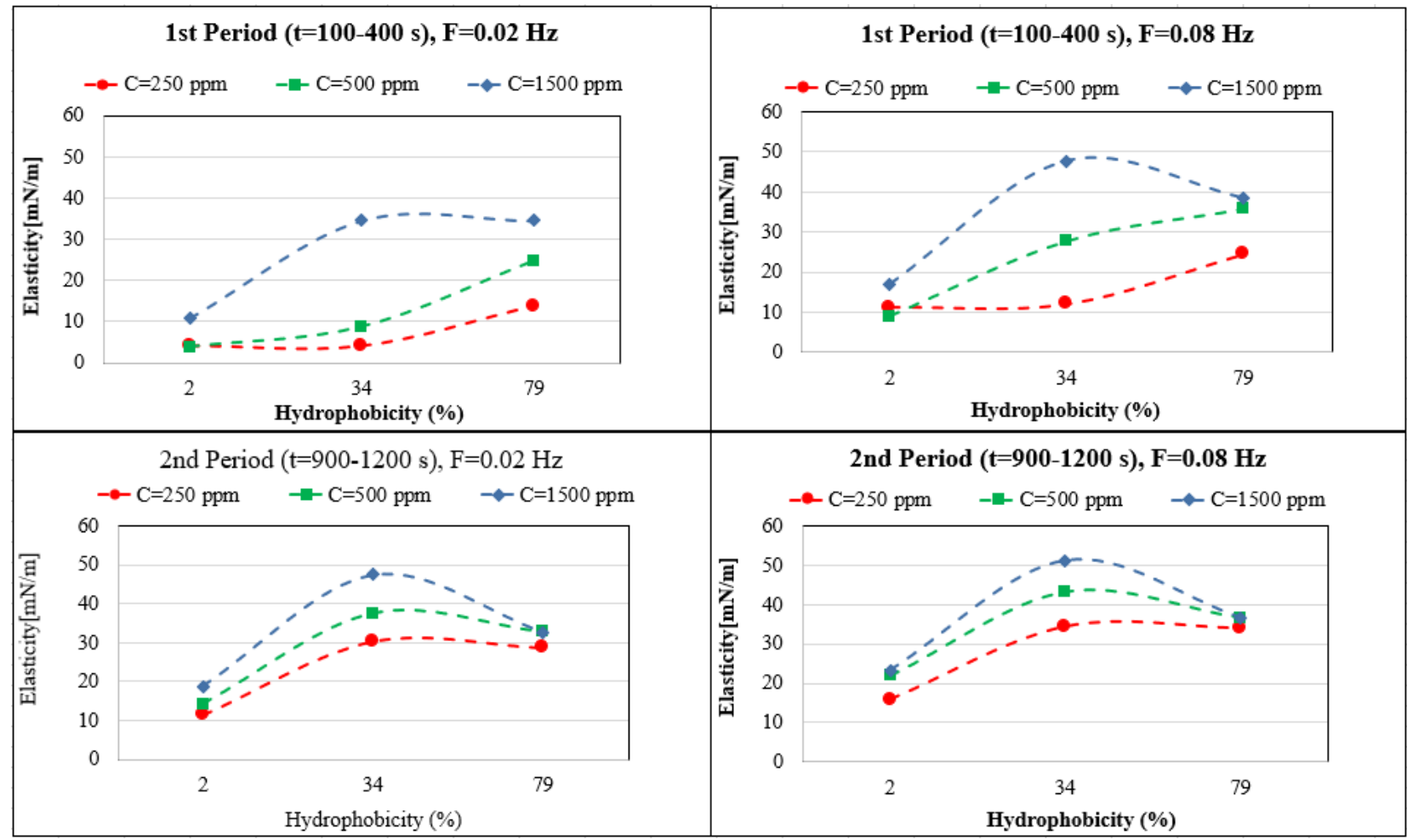

Figure 5. Dependency of the interfacial dilational elasticity on the bacteria's hydrophobicity for different adsorbed layer age and applied frequency $\mathrm{F}$.

In conclusion, it can be observed that the interfacial elasticity, known as an important parameter for the stability of complex adsorbed layers and related multiphase systems like foams and emulsions, can be different not only for certain types of bacteria and concentrations, but can also depend very much on the adsorbed layer age. Moreover, it is strongly linked to the dynamics of adsorption and the applied perturbation frequencies. This issue is also discussed below in connection to the emulsion formation experiments.

\subsection{Evaluation of Emulsion Stabilization}

Among the three bacteria studied here, just RAG1 exhibited a good ability for stabilizing crude oil in brine emulsions under different conditions. This fact can be concluded from the results of dynamic interfacial tension measurements (Figure 2), in which RAG1 is the only bacterium with a sufficiently fast adsorption kinetics and sufficiently sharp and quick decrease in interfacial tension, which is required for the emulsion formation process. Moreover, the interfacial elasticity factor which can play a certain role (however complex) on the stability of the formed emulsion, is in a reasonable correlation with this result. For the emulsification process, in which the interface between the phases is formed in a short time, the dynamic surface tension at short times and the elasticity values in early stages, at high frequencies, can support the formation of high volume emulsions with a better stability. It is observed in Figure 5 that the elasticity values of the early stages $(t=100-400 \mathrm{~s})$ at the high frequency of $0.08 \mathrm{~Hz}$, are considerably high just for RAG1 at low to high concentration solutions.

As for MEOR applications, the bacteria should play the expected role under high salinity conditions, the effects of the salinity on the crude oil in brine emulsions (stabilized by RAG1) is depicted in Figure 6. It is observed that firstly, the stability is improved by increasing the salinity in the low concentration range $(0.2 \% w / v)$. This can be related to the typical impacts of salt for enhancing the surface activity of amphiphilic components [40]. However, by a further increase in the salinity the initially formed emulsion volume and the stability decrease, which can be due to the secondary impacts of the salt on the denaturing 
process of the biological organisms and related key components. It should be noticed that although the overall salinity has negative effects on the emulsion stability, for RAG1 up to a very high salinity concentration of $20 \%$ a certain emulsion formation ability and stability can be observed. This demonstrates that the studied microorganism cells can tolerate harsh saline conditions in petroleum reservoirs.

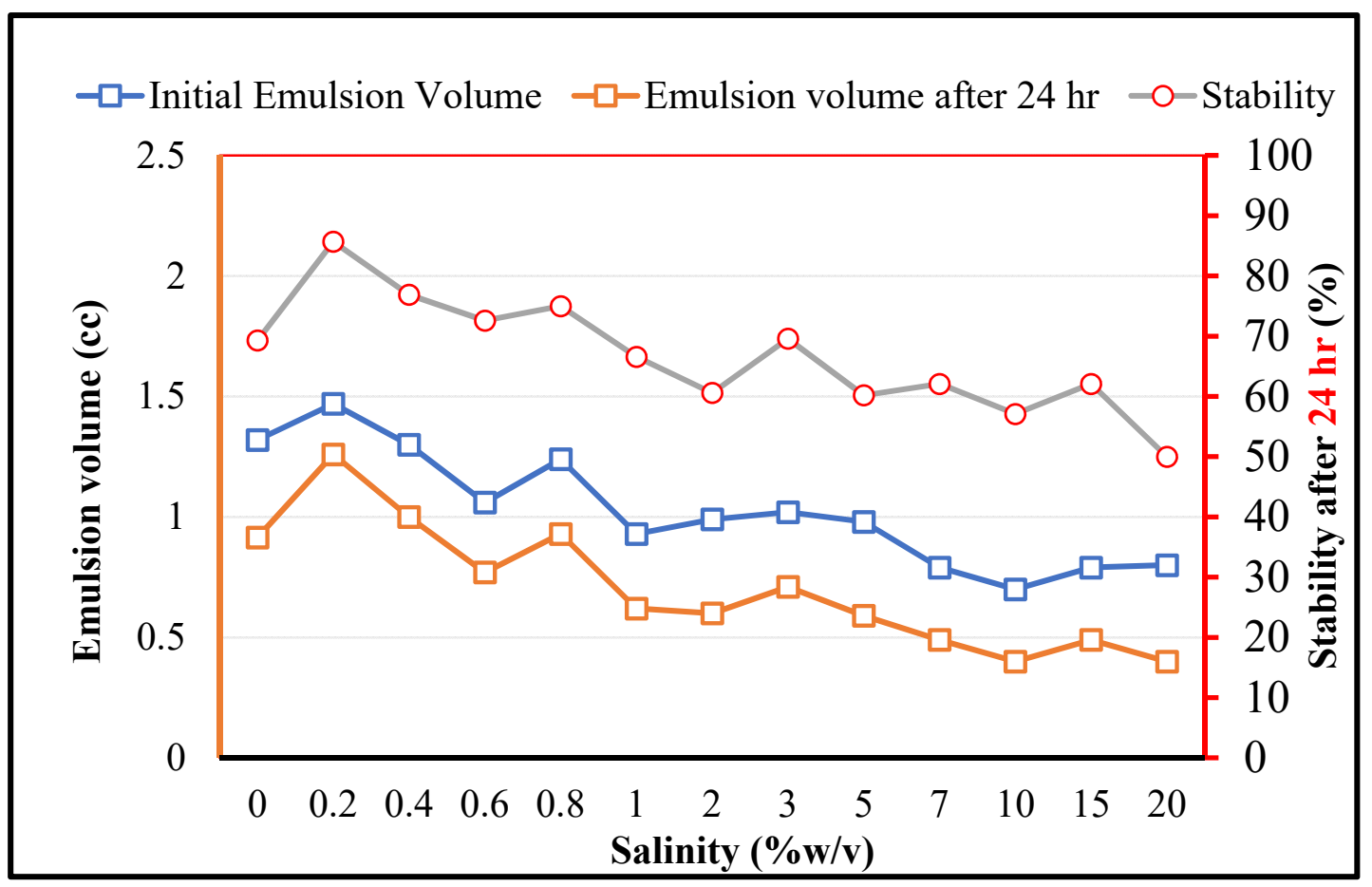

Figure 6. The impact of salinity on the crude oil in brine emulsions stabilized by RAG1 bacteria cells (1500 ppm).

There is also an interesting phase behavior of the emulsions stabilized by RAG1 at different salinities, as shown in Figure 7. At all salinities, three phases exist simultaneously: oil (containing some solubilized brine droplets), brine (containing some solubilized oil droplets), and the emulsion phase in between. Extensive research on the phase behavior of the emulsions stabilized by surfactants in brine show that depending on the salinity, three structures might occur. At low salinities, two phases exist-a pure oil phase in coexistence with a brine microemulsion phase that contains surfactant and some solubilized oil (this behavior is called Winsor type I). At high salinities, two phases also coexist-a brine phase and an oil microemulsion phase that contains surfactant and some solubilized brine (this behavior is called Winsor type II). At intermediate salinities three phases coexist: a brine phase, an oil phase and a microemulsion phase, which contains surfactant, brine, and oil (this behavior is called Winsor type III) [41].

Thus, emulsions that are formed and stabilized by RAG1 bacteria cells show a considerably different behavior as compared to surfactants. During surfactant flooding in reservoirs at high salinity brines, the formation of a water-in-oil emulsion is observed, which leads to an oil recovery reduction and further production problems [42]. However, for suspensions of RAG1 cells, although at high salinities less emulsion is formed, the emulsion will be of Winsor type III, which is the best emulsion type for the EOR [43]. Therefore, in EOR applications, less salinity independence can be favorable for the use of RAG1 cells as compared to surfactants. 


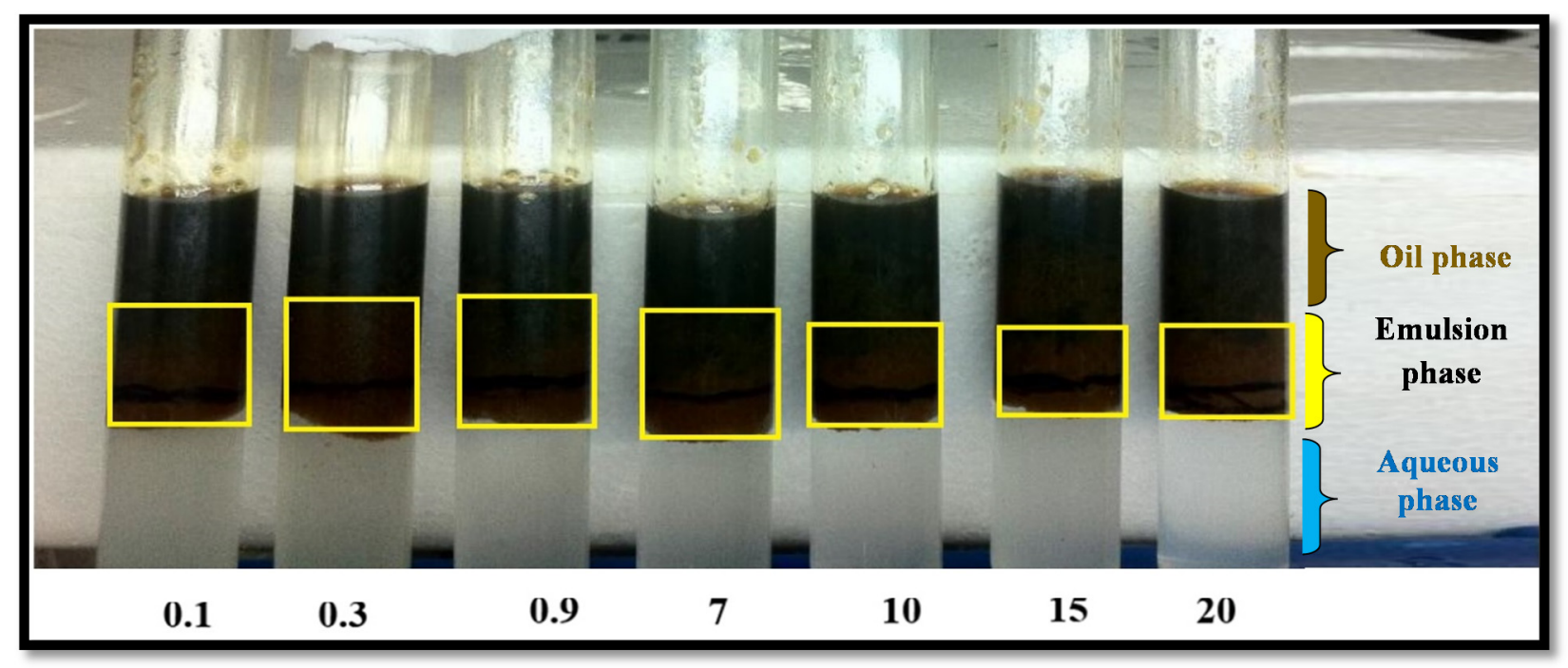

Figure 7. Phase behavior of crude oil in brine emulsions stabilized by RAG1 cells (1500 ppm) at different salinities in $\% w / v$.

\section{Conclusions}

The results of this work illustrate the importance of the natural surface properties of bacteria cells (not only via the produced biosurfactants) on the interfacial properties of water/oil interfaces. Three bacteria with different hydrophobicity factors $(\mathrm{H}=2,34$, and $79 \%$, respectively) were investigated in this regard, considering their direct impacts on the water/heptane interfacial tension (IFT) and corresponding interfacial dilational elasticity. The results demonstrate a significant dependency of the adsorption dynamics and IFT reduction on the hydrophobicity properties of the bacteria cells. The cells with the higher hydrophobicity factor (79\%) show a very fast adsorption kinetics and large elasticity values at short adsorption times. At long adsorption times, the bacteria with medium hydrophobicity factor $(\mathrm{H}=34 \%)$ show the highest elasticity among the three studied bacteria samples. The variations of the elastic properties show a complex behavior depending on the hydrophobicity, adsorption time, and bacteria concentration. It is observed that for low and intermediate concentrations (250 and $500 \mathrm{ppm})$, the RAG1 cells $(\mathrm{H}=79 \%)$ show a maximum elasticity for the first period of adsorption (100-400 s); however, for the highest concentration of 1500 ppm, MJ02 shows the highest elasticity for the first period of adsorption. For longer adsorption times (2nd period, 900-1200 s), MJ02 shows maximum elasticity values for all concentrations. For RAG1 at high concentrations, the elasticity at the measured frequencies of 0.02 and $0.08 \mathrm{~Hz}$ decreases, which is caused by the fast kinetics of adsorption. Note, the results can be different for very high frequencies, for which however alternative experimental techniques are required (which are not used in this work). It was demonstrated that the values of the interfacial elasticity, which is known as an important parameter for the stability of foams and emulsions, can be different not only for the certain types of bacteria and their concentrations, but can also strongly depend on the adsorbed layer age and the dynamics of adsorption.

The presented emulsification studies show that among these three bacteria samples, RAG1 provides a good capability to stabilize crude oil in brine emulsions, which can be well understood via studies of the dynamics of adsorption, i.e., the fast reduction of the IFT. The results illustrate that $R A G 1$ bacteria cells are able to stabilize emulsions at low $(0.2 \mathrm{w} \%)$ and also at very high salt concentration (20\%), which is a very suitable range for MEOR under practical conditions.

Author Contributions: E.G.-A., A.J., M.J.V., S.A. and R.M. conceived the investigations; E.G.-A., A.J., M.J.V. and S.A. designed and performed the experiments; E.G.-A., A.J., M.J.V., S.A. and R.M. wrote the manuscript. All authors have read and agreed with the published version of the manuscript.

Funding: This research received no external funding. 
Institutional Review Board Statement: Not applicable.

Informed Consent Statement: Not applicable.

Data Availability Statement: Not applicable.

Acknowledgments: Authors would like to thank the staff of the Surface Phenomena Lab. of the University of Tehran and the Enhanced Oil Recovery Lab. of Sharif University of Technology.

Conflicts of Interest: The authors declare no conflict of interest.

\section{References}

1. Al-Sulaimani, H.; Joshi, S.; Al-Wahaibi, Y.; Al-Bahry, S.; Elshafie, A.; Al-Bemani, A. Microbial biotechnology for enhancing oil recovery: Current developments and future prospects. Biotechnol. Bioinf. Bioeng. 2011, 1, 147-158.

2. Sarafzadeh, P.; Hezave, A.Z.; Ravanbakhsh, M.; Niazi, A.; Ayatollahi, S. Enterobacter cloacae as biosurfactant producing bacterium: Differentiating its effects on interfacial tension and wettability alteration mechanisms for oil recovery during MEOR process. Colloids Surf. B Biointerfaces 2013, 105, 223-229. [CrossRef] [PubMed]

3. Sivasankar, P.; Kumar, G.S. Numerical modelling of enhanced oil recovery by microbial flooding under non-isothermal conditions. J. Pet. Sci. Technol. 2014, 124, 161-172. [CrossRef]

4. Niu, J.; Liu, Q.; Lv, J.; Peng, B. Review on microbial enhanced oil recovery: Mechanisms, modeling and field trials. J. Pet. Sci. Eng. 2020, 192, 107350. [CrossRef]

5. Kaster, K.M.; Hiorth, A.; Kjeilen-Eilertsen, G.; Boccadoro, K.; Lohne, A.; Berland, H.; Stavland, A.; Brakstad, O.G. Mechanisms involved in microbially enhanced oil recovery. Transp. Porous Media 2012, 91, 59-79. [CrossRef]

6. Lazar, I.; Petrisor, I.; Yen, T. Microbial enhanced oil recovery (MEOR). Pet. Sci. Technol. 2007, 25, 1353-1366. [CrossRef]

7. Soudmand-asli, A.; Ayatollahi, S.S.; Mohabatkar, H.; Zareie, M.; Shariatpanahi, S.F. The in situ microbial enhanced oil recovery in fractured porous media. J. Pet. Sci. Technol. 2007, 58, 161-172. [CrossRef]

8. Sivakumar, N.; Al-Bahry, S.; Al-Battashi, H.S. Screening of Biopolymer Producing Bacteria Isolated from Some Brassica Plants. APCBEE Procedia 2013, 5, 333-338. [CrossRef]

9. Armstrong, R.T.; Wildenschild, D. Investigating the pore-scale mechanisms of microbial enhanced oil recovery. J. Pet. Sci. Technol. 2012, 94, 155-164. [CrossRef]

10. Wang, X.; Li, X.; Yu, L.; Li, Y.; Huang, L.; Lin, W.; Li, D. Distinctive microbial communities imply the main mechanism in a MEOR trial in high pour-point reservoir. J. Pet. Sci. Eng. 2019, 175, 97-107. [CrossRef]

11. Jeong, M.S.; Lee, J.H.; Lee, K.S. Critical review on the numerical modeling of in-situ microbial enhanced oil recovery processes. Biochem. Eng. J. 2019, 150, 107294. [CrossRef]

12. She, H.; Kong, D.; Li, Y.; Hu, Z.; Guo, H. Recent advance of microbial enhanced oil recovery (MEOR) in China. Geofluids 2019, 1871392. [CrossRef]

13. Karimi, M.; Mahmoodi, M.; Niazi, A.; Al-Wahaibi, Y.; Ayatollahi, S. Investigating wettability alteration during MEOR process, a micro/macro scale analysis. Colloids Surf. B Biointerfaces 2012, 95, 129-136. [CrossRef] [PubMed]

14. Sarafzadeh, P.; Hezave, A.Z.; Mohammadi, S.; Niazi, A.; Ayatollahi, S. Modification of rock/fluid and fluid/fluid interfaces during MEOR processes, using two biosurfactant producing strains of Bacillus stearothermophilus SUCPM\# 14 and Enterobacter cloacae: A mechanistic study. Colloids Surf. B Biointerfaces 2014, 117, 457-465. [PubMed]

15. Dorobantu, L.S.; Yeung, A.K.; Foght, J.M.; Gray, M.R. Stabilization of oil-water emulsions by hydrophobic bacteria. Appl. Environ. Microbiol. 2004, 70, 6333-6336. [CrossRef]

16. Kang, Z.; Yeung, A.; Foght, J.M.; Gray, M.R. Hydrophobic bacteria at the hexadecane-water interface: Examination of micrometrescale interfacial properties. Colloids Surf. B Biointerfaces 2008, 67, 59-66. [CrossRef]

17. Kang, Z.; Yeung, A.; Foght, J.M.; Gray, M.R. Mechanical properties of hexadecane-water interfaces with adsorbed hydrophobic bacteria. Colloids Surf. B Biointerfaces 2008, 62, 273-279. [CrossRef]

18. Halim, A.Y.; Nielsen, S.M.; Nielsen, K.F.; Lantz, A.E. CPC TESTING: Towards the understanding of microbial metabolism in relation to microbial enhanced oil recovery. J. Pet. Sci. Eng. 2017, 149, 151-160. [CrossRef]

19. Kögler, F.; Dopffel, N.; Mahler, E.; Hartmann, F.S.F.; Schulze-Makuch, D.; Visser, F.; Frommherz, B.; Herold, A.; Alkan, H. Influence of surface mineralogy on the activity of Halanaerobium sp. during microbial enhanced oil recovery (MEOR). Fuel 2021, 290, 119973. [CrossRef]

20. Smyth, T.; Perfumo, A.; Marchant, R.; Banat, I. Isolation and analysis of low molecular weight microbial glycolipids. In Handbook of Hydrocarbon and Lipid Microbiology; Springer: Berlin/Heidelberg, Germany, 2010; pp. 3705-3723.

21. Taber, J.J. Research on Enhanced Oil Recovery: Past, Present and Future, Surface Phenomena in Enhanced Oil Recovery; Springer: Berlin/Heidelberg, Germany, 1981; pp. 13-52.

22. Quintero, D.A.A. Flow of Macroemulsions through Porous Media; Stanford University: Stanford, CA, USA, 1974.

23. Peng, F.; Liu, Z.; Wang, L.; Shao, Z. An oil-degrading bacterium: Rhodococcus erythropolis strain 3C-9 and its biosurfactants. J. Appl. Microbiol. 2007, 102, 1603-1611. [CrossRef]

24. Gudiña, E.J.; Pereira, J.F.; Rodrigues, L.R.; Coutinho, J.A.; Teixeira, J.A. Isolation and study of microorganisms from oil samples for application in microbial enhanced oil recovery. Int. Biodeterior. Biodegrad. 2012, 68, 56-64. [CrossRef] 
25. Bushnell, L.; Haas, H. The utilization of certain hydrocarbons by microorganisms. J. Bacteriol. 1941, 41, 653. [CrossRef] [PubMed]

26. Atlas, R.M. Handbook of Media for Environmental Microbiology; CRC Press: Boca Raton, FL, USA, 2005.

27. Weisburg, W.G.; Barns, S.M.; Pelletier, D.A.; Lane, D.J. 16S ribosomal DNA amplification for phylogenetic study. J. Bacteriol. 1991, 173, 697-703. [CrossRef]

28. Lotfabad, T.B.; Shourian, M.; Roostaazad, R.; Najafabadi, A.R.; Adelzadeh, M.R.; Noghabi, K.A. An efficient biosurfactantproducing bacterium Pseudomonas aeruginosa MR01, isolated from oil excavation areas in south of Iran. Colloids Surf. B Biointerfaces 2009, 69, 183-193. [CrossRef] [PubMed]

29. Veshareh, M.J.; Azad, E.G.; Deihimi, T.; Niazi, A.; Ayatollahi, S. Isolation and screening of Bacillus subtilis MJ01 for MEOR application: Biosurfactant characterization, production optimization and wetting effect on carbonate surfaces. J. Pet. Explor. Prod. Technol. 2018, 9, 1-13.

30. Deihimi, T.; Ebrahimie, E.; Niazi, A.; Ebrahimi, M.; Ayatollahi, S.; Tahmasebi, A.; Rahimi, T.; Veshareh, M.J. Systems Biology Analysis of the Key Genes of Surfactin Production in Bacillus subtilis MJ01 (Isolated from Soil Contaminated Oil in South of Iran), Spizizenii, and 168 Isolates. J. Cell Mol. Res. 2017, 9, 84-97.

31. Rosenberg, M. Bacterial adherence to hydrocarbons: A useful technique for studying cell surface hydrophobicity. FEMS Microbiol. Lett. 1984, 22, 289-295. [CrossRef]

32. Loglio, G.; Pandolfini, P.; Miller, R.; Makievski, A.; Ravera, F.; Ferrari, M.; Liggieri, L. Drop and bubble shape analysis as tool for dilational rheology studies of interfacial layers. In Novel Methods to Study Interfacial Layers; Elsevier Science: Amsterdam, The Netherlands, 2001; pp. 439-484.

33. Javadi, A.; Mucic, N.; Karbaschi, M.; Won, J.; Lotfi, M.; Dan, A.; Ulaganathan, V.; Gochev, G.; Makievski, A.; Kovalchuk, V. Characterization methods for liquid interfacial layers. Eur. Phys. J. Spec. Top. 2013, 222, 7-29. [CrossRef]

34. Miller, R.; Liggieri, L. Interfacial Rheology; CRC Press: Boca Raton, FL, USA, 2009.

35. Miller, R.; Kretzschmar, G. Adsorption kinetics of surfactants at fluid interfaces. Adv. Colloid Interface Sci. 1991, 37, 97-121. [CrossRef]

36. Fainerman, V.; Makievski, A.; Miller, R. The analysis of dynamic surface tension of sodium alkyl sulphate solutions, based on asymptotic equations of adsorption kinetic theory. Colloids Surf. A Physicochem. Eng. Asp. 1994, 87, 61-75. [CrossRef]

37. Bechinger, C.; di Leonardo, R.; Löwen, H.; Reichhardt, C.; Volpe, G.; Volpe, G. Active particles in complex and crowded environments. Rev. Mod. Phys. 2016, 88, 045006. [CrossRef]

38. Javadi, A.; Krägel, J.; Makievski, A.; Kovalchuk, V.; Kovalchuk, N.; Mucic, N.; Loglio, G.; Pandolfini, P.; Karbaschi, M.; Miller R. Fast dynamic interfacial tension measurements and dilational rheology of interfacial layers by using the capillary pressure technique. Colloids Surf. A Physicochem. Eng. Asp. 2012, 407, 159-168. [CrossRef]

39. Tadros, T. Encyclopedia of Colloid and Interface Science; Springer: Berlin/Heidelberg, Germany, 2013.

40. Mahmoudvand, M.; Javadi, A.; Pourafshary, P. Brine ions impacts on water-oil dynamic interfacial properties considering asphaltene and maltene constituents. Colloids Surf. A Physicochem. Eng. Asp. 2019, 579, 123665. [CrossRef]

41. Winsor, P.A. Solvent Properties of Amphiphilic Compounds; Butterworths Scientific Publications: London, UK, 1954.

42. Rezaei, N.; Firoozabadi, A. Macro-and microscale waterflooding performances of crudes which form w/o emulsions upon mixing with brines. Energy Fuels 2014, 28, 2092-2103. [CrossRef]

43. Bera, A.; Ojha, K.; Mandal, A.; Kumar, T. Interfacial tension and phase behavior of surfactant-brine-oil system. Colloids Surf. A Physicochem. Eng. Asp. 2011, 383, 114-119. [CrossRef] 